\title{
HSP90 expression in two migratory cell types during ascidian development: test cells deposit HSP90 on the larval tunic
}

\author{
CORY D. BISHOP*,1, BRIAN K. HALL² and WILLIAM R. BATES ${ }^{3}$ \\ ${ }^{1}$ Department of Biology, St. Francis-Xavier University, Antigonish, NS, Canada, ${ }^{2}$ Department of Biology, \\ Dalhousie University, Halifax, NS, Canada and ${ }^{3}$ Department of Biology and Physical Geography, Irving K. \\ Barber School of Arts and Sciences, University of British Columbia, Okanagan, Kelowna, BC, Canada
}

\begin{abstract}
Heat shock protein 90 (HSP90) is a ubiquitously expressed molecular chaperone that controls the folding, assembly and activity of proteins, many of which are involved in signal transduction. Recent work has shown that HSP90 is present extracellularly, indicating a heretofore under appreciated requirement for extracellular chaperoning, particularly among migratory cells. We applied immunological and surgical techniques to document the differential expression of HSP90 during ascidian development. Relative to other cell types during development, test cells and trunk lateral cells (TLCs), two migratory cell types in the ascidian Boltenia villosa, express elevated levels of HSP90. Late in embryogenesis, test cells deposit HSP90 onto the tunic, the second report of extracellular HSP90 during animal development. The pyurid ascidian Halocynthia igaboja and the styelids Cnemidocarpa finmarkiensis and Botrylloides violaceus all express HSP90 at elevated levels in larval mesenchyme, suggesting that this pattern of expression is widespread in the Ascidiaceae. We show that HSP90 expression in TLCs and test cells is coincident with the presence of HNK-1. Whereas in B. violaceous, cell populations expressing elevated levels of HSP90 are distinct from those expressing HNK-1, in $B$. villosa both these antigens are present in the TLCs. We evaluate existing hypotheses about test cell function and, in reference to the similarities between test cells and some of the descendants of TLCs, hypothesize that test cells are TLC descendants. Implications for the proposed evolutionary relationship between TLCs and neural crest are briefly discussed.
\end{abstract}

KEY WORDS: HSP90, test cells, TLC, ascidian

Among marine invertebrates, ascidians are unique in both their mode of larval locomotion and their possession of a protective extracellular matrix, the tunic. The tunic is composed of carbohydrate polymers and proteins that interact extensively (Smith and Dehnel, 1970). In adult and larval stages of ascidians, the tunic is secreted by epidermal cells (Wardrop 1970; Robinson et al., 1986). In embryos and larvae the tunic appears to require the presence of test cells, a third unique characteristic of ascidian embryos.

Test cells are extraembryonic migratory cells that reside between the embryo and the follicular envelope of almost all ascidian embryos. The rarity of test cell analogues in the animal kingdom is conspicuous and the ontogenetic origin and function of test cells remains enigmatic. Test cells are thought by some authors to derive from the inner follicular envelope, which, in turn, arises from the germinal epithelium (Cloney, 1994 and references therein). Another hypothesis is that test cells derive from migratory amoeboid or lymphocyte cells that differentiate into test cells and become preferentially associated with developing oocytes (Cloney, 1994). In either case, investigation of test cell origins has not yielded as much insight into their function as has that of their remarkable behavior.

Test cells are migratory throughout development, and in later stages, form large aggregates that collectively migrate over the surface of the embryo (Fig. 1). In larvae of some species, test cells become embedded in the larval tunic and, at least in Ciona intestinalis, retain their migratory behavior (Sato et al., 1997); in larvae of other species test cells do not adhere to the larval tunic

Abbreviations used in this paper: HNK-1, human natural killer antigen 1; HSP90, heat shock protein 90; TLCs, trunk lateral cells.

\footnotetext{
*Address correspondence to: Cory D. Bishop. Department of Biology, St. Francis-Xavier University, 2320 Notre Dame Ave, NS, B2G 2W5 Canada. e-mail: cbishop@stfx.ca
} 

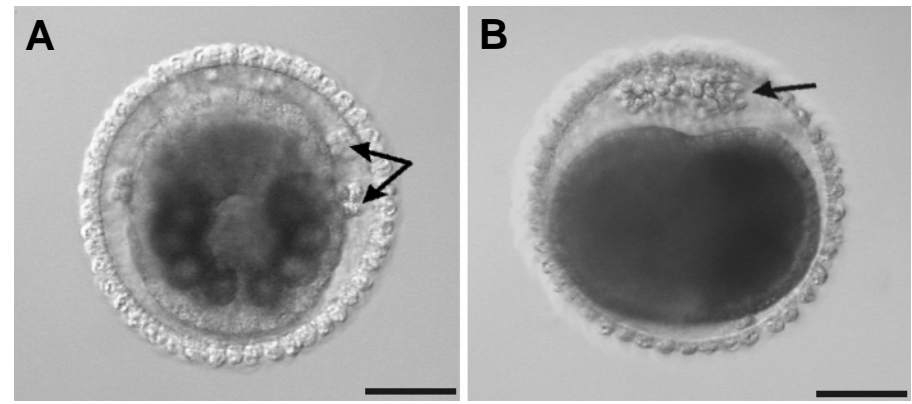

Fig. 1. Images of test cells aggregating and migrating around the outer surface of $\boldsymbol{B}$. villosa embryos. (A) Gastrula in vegetal view. (B) Neurula in lateral view. Arrows in $(A, B)$ point to test cells. Scale bars, $40 \mu \mathrm{m}$.

after hatching (Cloney, 1990). Cavey (1976) demonstrated that test cells of Distaplia occidentaliscontain and deposit granules on the larval tunic. This 'ornamentation' process was further documented for Corella inflata and Styela clava (Cloney and Cavey, 1982; Monniot et al., 1992b) and subsequently in 12 additional species (Cloney, 1994).

Interestingly, a survey of 16 species representing 10 families revealed that only larvae without firmly adhering test cells bear ornaments (Cloney, 1990). In some species, silica (in the form of opal) is a component of these granular ornaments (Monniot et al., 1992b). The electron density of these granules was sensitive to pronase digestion, leading to the proposition that the silica was complexed with proteins (Monniot et al., 1992b). Consistent with these observations, the secretion of antigens from test cells to the tunic surface has been demonstrated using immunocytochemical approaches at both the light and the electron microscopic levels (Takamura et al., 1996; Okada et al., 1996). Because the nature of the antigens was not characterized in these reports, no specific proteins secreted from test cells have been identified. Test cells in Styela plicata contain and can be induced to release, heparin and histamine (Cavalcante et al., 2000; Cavalcante et al., 2002), supporting an interpretation of immune-like function. The common conclusions derived from these reports are that test cells contain and deposit molecules that modify the external surface of the larval tunic. But to what end?

Removal of test cells by dechorionation of embryos at various developmental stages indicated that test cells participate directly in morphogenesis of the dorsal, caudal and ventral fins of the larval tunic and determine its degree of hydrophobicity (Cloney and Cavey, 1982; Robinson et al., 1986). Subsequently however, Cloney (1990) found that when dechorionated Ascidia callosa and Corella inflataembryos were cultured at higher densities, the

TABLE 1

\section{FATES OF THE A7.6 LINEAGE IDENTIFIED BY DIFFERENT TRACING TECHNIQUES IN TWO SOLITARY ASCIDIANS}

\begin{tabular}{ll} 
Species & Fates (function inferred from position or morphology) \\
\hline C. savigny & -ciliary epithelium on gill slits of branchial basket \\
& -oral siphon muscle \\
& -blood cells \\
& -tunic cells and tunic granules \\
& -gut \\
& -ciliary epithelium on gill slits of branchial basket \\
H. roretzi & -longitudinal mantle muscle, oral siphon muscle \\
& -blood cells \\
\hline
\end{tabular}

morphology of the tunic was restored; that is, the absence of test cells can be rescued. He concluded that a diffusible 'factor' from embryos is responsible for this behavior and that the function of test cells is to impart hydrophilicity to an otherwise hydrophobic tunic (Cloney, 1990). Remarkably, in Ciona intestinalis, removing test cells resulted in the emigration of new cells from the embryo which then re-populated the tunic in a manner reminiscent of the original test cell population (Sato and Morissawa 1999). During metamorphosis, a reduced efficiency of tail resorption (a primary metamorphic event) relative to the rotation of rudimentary juvenile tissues (a secondary metamorphic event) was also observed among larvae lacking the original test cell population (Sato et al., 1999). A role for test cells in coordinating morphogenetic events during metamorphosis was thus proposed, but the possibility that the replacement cells normally participate in metamorphosis was not. Cloney (1990) discussed the finding that, despite careful removal of test cells among his dechorionated embryos, he occasionally found test cells attached to larval surfaces. He may have been observing the replacement cells reported by Sato and Morisawa (1999).

Similar to the larval tunic, the adult tunic is populated by migratory 'blood' cells, some of which are more numerous in the tunic than in the animal proper (Smith, 1970). A fraction of these cells is derived from the trunk lateral cells (TLCs) (Hirano and Nishida, 1997, Tokuoka et al., 2005). At the hatching stage TLCs are positioned as two bilaterally symmetrical groups of mesenchyme in the posterior dorsal trunk region. After hatching and prior to metamorphosis TLCs migrate extensively in an anterior and ventral direction (Nishide et al., 1989). As one of multiple migratory mesenchyme populations that exist in ascidian larvae, TLCs have no known function during the larval stage and thus have been presumed to be uniquely adult precursor cells. During metamorphosis, some TLCs cross the epithelium to the exterior of the animal (Nishide et al., 1989) and reside in the tunic of the juvenile (Tokuoka et al., 2005). Other known fates of the TLCs are listed in Table 1. In both Halocynthia roretziand Ciona savigny TLCs are derived from the A7.6 blastomeres, which are fate restricted at the 64-cell stage (Nishida and Satoh, 1987). Thus, although the origins of TLCs and test cells are (at least temporally) distinct, it is notable that both cell types are migratory and that each associates with the adult and larval tunics, respectively.

Here we build upon these relationships between test cells and TLCs by reporting that both cell types express elevated levels of the protein chaperone HSP90 relative to other embryonic and larval tissues in the pyurid ascidian Boltenia villosa. We show that test cells release HSP90 on to the larval tunic during tail elongation. We discuss the shared properties of test cells and TLCs and advance the hypothesis that test cells are descendants of TLCs. We show the ubiquity of HSP90 expression in TLCs, by documenting elevated expression in Cnemidocarpa finmarkiensis, Halocynthia igaboja and Botrylloides violaceus. Finally, whereas HSP90 and HNK-1 antibodies label TLCs in B. villosa, these markers label distinct cell populations in $B$. violaceous.

\section{Results}

Immunoreaction of test cells and trunk lateral cells to AC88

In first stage oocytes, the ooplasm is strongly immunoreactive to AC88 antiserum (Fig. 2A, arrowhead). No test or follicle cells 
are visible at this stage. In maturing oocytes, test cells become visible in sectioned material and immunoreactivity of test cells to AC88 is detected (Fig 2A, arrows). In contrast, eggs have low levels of AC88 immunoreactivity relative to test cells (Fig. 2B). The immunoreactivity of AC88 to test cells was also documented in neurulae and midtail embryos (Fig. 2E-H). Frequently the immunoreaction is visible in a punctate pattern.

Around the time of neurulation in $B$. villosa, the test cells migrate to form clusters of cells, sometimes assembling into a single cluster (Fig. 1B), which collectively migrate(s) over the surface of the embryo. AC88 immunoreactivity in the test cells persisted beyond this stage until the mid-tail bud stage (Fig 2G). After this point we observed a striking shift in AC88 immunoreactivity from the test cells to the surface of the tunic (Fig. 2G,H). Immunoreactivity of the tunic to AC88 persisted after hatching (29-30 $\mathrm{h}$ post insemination at $\left.13^{\circ} \mathrm{C}\right)$, but decreased with the age of swimming larvae (data not shown). To test whether the deposition of HSP90 from test cells was responsible for the immunoreaction of AC88 to the tunic, we dechorionated embryos at the tail bud stage (which liberated the test cells), immunostained the resulting larvae and compared these to hatched controls. No immunoreaction to the tunic was observed among larvae from which the test cells were removed (Fig. $2 \mathrm{I}-\mathrm{K}$ ).

To verify that the AC88 antibody was detecting $B$. villosa HSP90 we performed an immunoblot of total embryonic or larval proteins. A single band (sometimes resolvable into two closely migrating species) was detected by the AC88 antibody at every embryonic and larval stage tested (Fig. 3A). This band migrated further than did the band for bovine HSP90 indicating a protein of approximately $80 \mathrm{kD}$. We determined the predicted size of ascidian HSP90 by performing an in silico translation using Expasy Proteomics Tools (http://ca.expasy.org/tools/) of Ciona intestinalis HSP90 identified from the JGI server (http://genome.jgi-psf.org/ Cioin2/Cioin2.home.html). Consistent with our immunoblotting results, the predicted Ciona protein is 727 aa long with a molecular mass of $83.4 \mathrm{kD}$, a result also reported in Chen et al., (2006). To further verify that the immunoreaction of test cells to AC88 corresponded to the presence of HSP90, twenty $B$. villosa zygotes were manually dechorionated, which liberated the test cells. Proteins from these and 20 control embryos were immunoblotted and probed with AC88. Taken together these results indicate that, relative to the zygote, test cells contain elevated
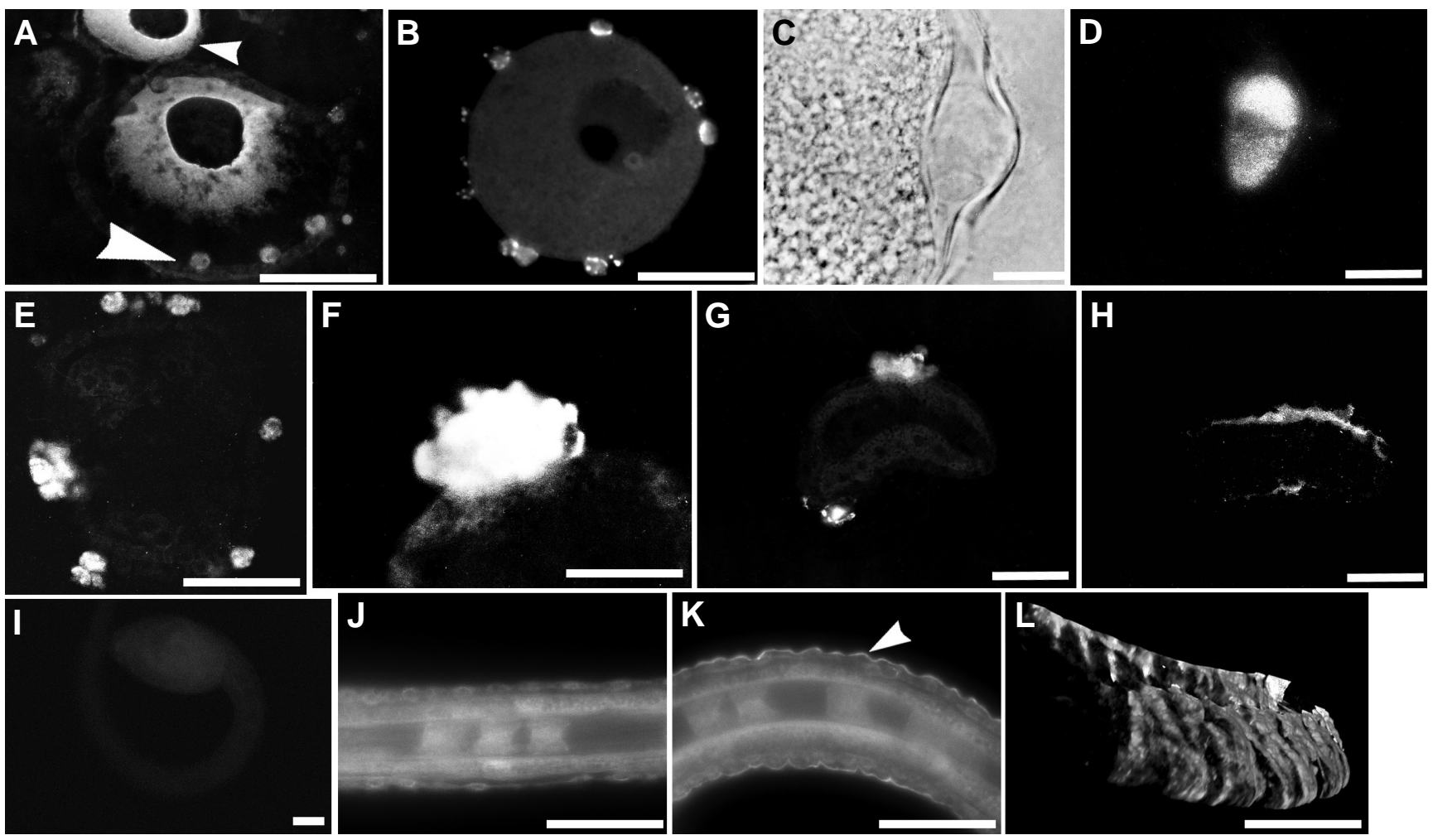

Fig. 2. Immunoreactivity of test cells and the larval tunic to AC88 during development in $\mathbf{B}$. villosa in sectioned (A-H) and in whole mount (IL) preparations. (A) Oocytes at two different stages of maturation dissected from B. villosa ovaries. The small arrowhead points to a pre-vitellogenic oocyte and the large arrowhead points to a test cell immunoreactive for AC88 in a vitellogenic oocyte. (B) Egg showing punctate AC88 immunoreactivity in the test cells. (C) Bright field view of a region of a sectioned egg containing a test cell. (D) The same section in (C) showing immunoreactivity exclusive to the test cell. (E) Section of a neurula stage embryo through the dorsal/ventral plane. Anterior is up, and note that the test cells have begun to aggregate. (F) Higher magnification of a cluster of test cells on the surface of a neurula stage embryo. (G) Sagittal section of a tailbud larva at 20 hours p.f. (H) Similar section of a developing tail as in (E) but at 22 hours p.f. The immunoreactivity to AC88 is no longer observed in test cells, but is now on the surface of the tail. (I-L) Whole mount preparations of larvae. (I) Negative control corresponding to panels (J-K) in which the primary antibody was omitted. (J) Larva from an embryo in which test cells were removed at the early tailbud stage. No immunoreaction to the tunic was observed. (K) Larva from unoperated controls. Arrowhead points to immunoreaction on the tunic. (L) A 3D projection of 145.27 $\mu$ m of a region of tail from a hatched control larva. Anterior is to the left. Scale bars in $(A, B) 70 \mu \mathrm{m} ;(C, D), 10 \mu \mathrm{m} ;(E-L), 50 \mu \mathrm{m}$. 


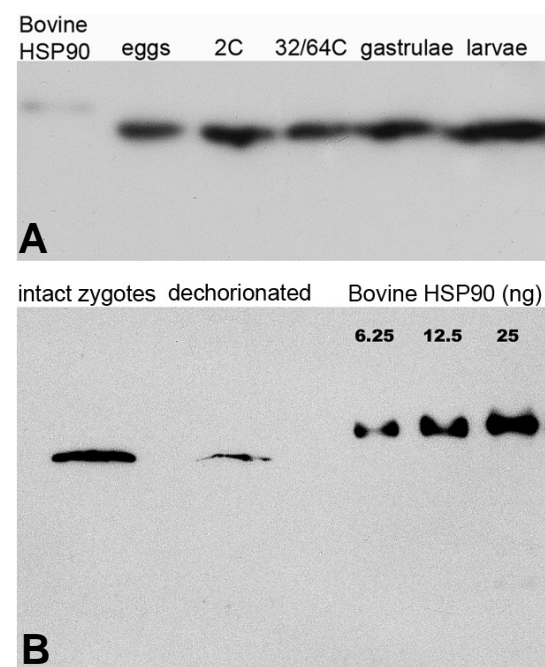

Fig. 3. Immunoblots of $B$. villosa embyronic and larval lysates probed with AC88. (A) Immunoblot of total cytosolic proteins from various developmental stages probed with AC88. A single polypeptide of $\sim 80 \mathrm{kD}$ is present in all stages. Purified bovine HPS90 was used as a positive control for the probe and as a reference for protein mobility among samples. (B) Immunoblot of total cytosolic proteins from 20 intact and dechorionated zygotes and increasing concentrations of bovine HSP9O.

levels of a protein with the electrophoretic and immunoreactive properties of HSP90 (Fig. 3B). We conclude that AC88 immunoreaction is HSP90 expression and henceforth refer to it accordingly.

\section{Elevated HSP90 expression in larval mesenchyme}

The other prevalent pattern of HSP90 expression in B. villosa was observed in mesenchyme originating in the larval posterior trunk (Fig. 4).'A punctate staining pattern became detectable in the cytoplasm of these cells within one hour of hatching (Fig. 4 $A, B)$; larvae fixed immediately after hatching showed no elevated staining in these cells (not shown). After elevated HSP90 becomes detectable in these cells, they begin to migrate anteriorly and ventrally (Fig. 4C). In sectioned larvae immunoreactive cells are often observed between the presumptive gut and the epidermis (Fig. 4D) and in the space between the anterior larval epidermis and the larval gut. This space becomes enlarged during larval life as the yolk in the presumptive gut is depleted. This position is maintained until metamorphosis is initiated, at which time immunostained cells can be seen exterior to the epidermis (Fig. 4E). Elevated levels of HSP90 are observed for up to 24 hours after metamorphosis (data not shown). In larvae that delay metamorphosis, immunoreactive cells are observable for longer than the elapsed time between hatching and 24 hours postmetamorphosis, indicating that the loss of HSP90 expression in these cells is associated with metamorphosis.

\section{Larval mesenchyme corresponds to the trunk lateral cells}

In the pyurid Halocynthia roretzi, TLCs are both migratory and occupy a position at hatching that is similar to the HSP90 positive cells that we describe here (Nishikata and Satoh, 1991). To test the possibility that TLCs in $B$. villosa express high levels of HSP90, we took advantage of the ascidian determinate cleavage pattern and ablated blastomeres in the embryo that give rise to TLCs. Cell lineage analysis indicates that the TLCs in $\mathrm{H}$. roretzi are derived from the A7.6 blastomeres situated on the vegetal side of the embryo (Nishida and Satoh, 1987). In order to test whether the HSP90 expressing cells in B. villosa larvae were TLCs, we ablated the A5.2 blastomeres. These blastomeres give rise to A7.5-A7.7 (presumptive endoderm, TLCs and notochord) and the A8.15 and A8.16 blastomeres (presumptive muscle and nerve cord) (Nishida and Satoh, 1987). Because we were employing manual cytolysis methods, the A5.2 blastomeres represented the latest point in development that we could reliably identify and ablate blastomeres. Embryos lacking the A5.2 lineage continued to cleave, gastrulated, neurulated (Fig. 4F) and developed into relatively normal looking larvae with recognizable axes (Fig. 4G). Larvae lacking the A5.2 descendants were fixed and sectioned for immunocytochemistry with AC88. No immunoreactive cells were observed among larvae lacking the descendants of the A5.2

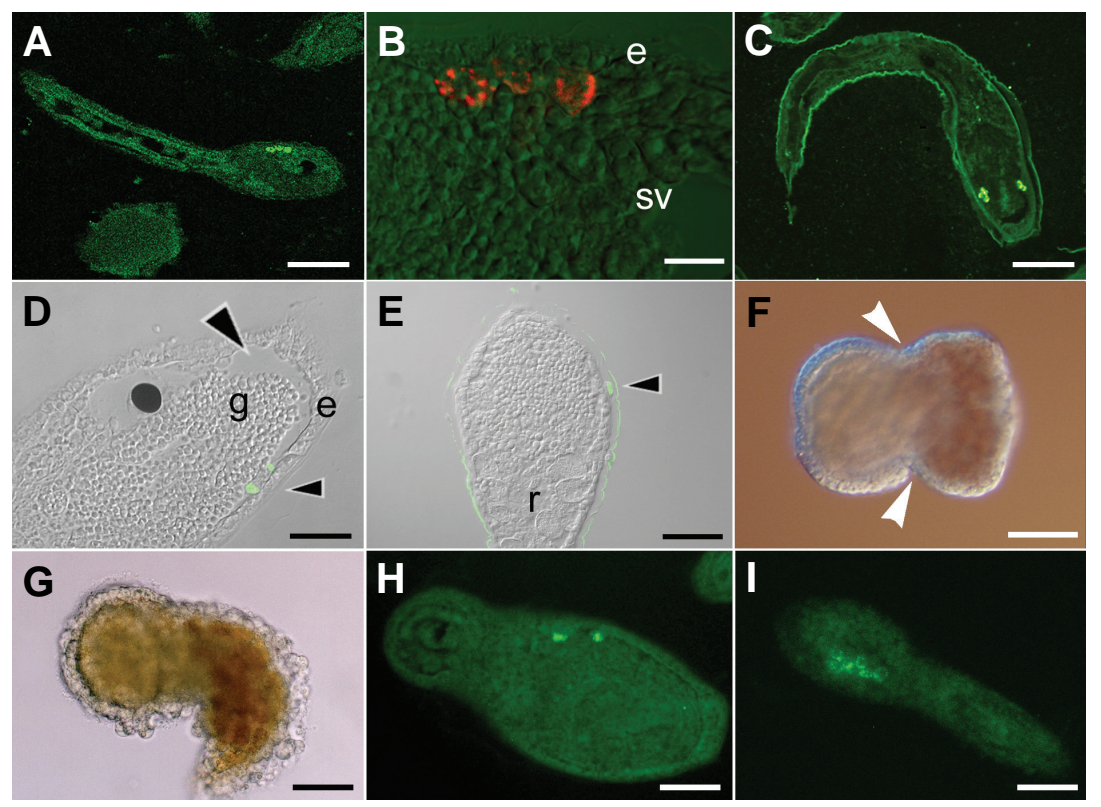

Fig. 4. Immunoreactivity of larval mesenchyme cells with AC88 antibody. (A) Sagittal section of a newly hatched larva prior to the migration of mesenchyme. (B) Confocal image of the position of pre-migratory mesenchyme relative to the dorsal epidermis (e) and the sensory vesicle (SV). Note the punctate pattern of staining. (C) A hatched larva sectioned along the dorsal-ventral axis. Two pockets of mesenchyme are positioned symmetrically around the midline as they migrate anteriorly. Although these cells are cohesive, in other preparations they migrate as independent cells. (D) Sagittal section of a hatched larva showing a single immunoreactive mesenchyme cell (small arrowhead) positioned between the presumptive juvenile gut $(\mathrm{g})$ and the epidermis (e). 'AC88 immunoreactivity is restricted to the leading and trailing extremeties of this cell. Large arrowhead points to the final position of migrating TLCs before the initiation of metamorphosis. This and the following image were created by overlaying a DIC image with an fluorescent image. (E) Section of a larva that has initiated metamorphosis. Resorbed muscle cells (r) are evident in the posterior half of the zooid. Note the position of the immunoreactive cell exterior to the epidermis. (F) A live neurula/early tailbud embryo lacking the A5.2 descendants. Arrowheads point to the position of the extirpated A5.2 lineage descendants. (G) Image of a live larva lacking the descendants of the A5.2 lineage. This and other larvae from which the A5.2 lineage was removed were sectioned and immunostained with AC88. (H) Sagittal section of the trunk region of a H. igaboja hatched larva immunoreactive for AC88. (I) Sagittal section of a C. finmarkiensis larva immunoreactive for AC88. Scale bars are $100 \mu \mathrm{m}$ in (A); $10 \mu \mathrm{m}$ in (B); $50 \mu \mathrm{m}$ in $(C, F-I)$ and $25 \mu \mathrm{m}$ in $(D, E)$. 
lineage. Thirty-nine percent (100/279) of sections of control larvae examined contained one or more immunoreactive cells, whereas $0 \%(0 / 110)$ of the sections derived from larvae lacking the A5.2 lineage contained immunoreactive cells.

\section{Elevated HSP90 expression in larval mesenchyme of other species.}

To test whether the pattern of HSP90 expression in $B$. villosa was unique we performed immunostaining on three additional species. The pyurid $H$. igaboja and the styelids $C$. finmarkiensis and $B$. violaceus display a similar pattern of HSP90 expression in mesenchyme of the trunk (Fig. 4 $\mathrm{H}, \mathrm{I}$; Fig. $5 \mathrm{~A}, \mathrm{~B})$. We assume that these are TLCs. The punctate character of the label supports this assumption. Interestingly, in $B$. violaceus protostigmata expressed elevated levels of HSP90 in a heterogeneous fashion (Fig. $5 \mathrm{C})$. Higher magnification views show this staining to be punctate, as in HSP90 positive mesenchymal cells (Fig. 5D).

We hypothesized that the HSP90 positive cells in $B$. violaceus were the same as the HNK-1 positive cells reported in Jeffery (2006). To test this, we double stained sections of $B$. violaceusembryos and larvae with AC88 and anti-HNK-1 (5G-I). Despite their spatial coincidence, we observed no cells in which both antigens were present, indicating that, with respect to HSP9O and HNK-1, these cell populations are developmentally distinct at this stage. In marked contrast, when we conducted the same double staining experiment with sections of $B$. villosa larvae we observed that HSP90 and HNK-1 are present in the same cell, namely the TLCs (Fig $5 \mathrm{~J}-\mathrm{L}$ ). To our surprise, we also observed that the test cells in $B$. villosa eggs are immunoreactive to anti-HNK-1 (Fig. $5 \mathrm{M}-\mathrm{O}$ ). Double staining experiments indicated that while HSP90 and HNK-1 are both present in the test cells their patterns of immunoreactivity are distinct, suggesting that their subcellular localizations do not overlap. As with AC88, the tunic of hatched larvae was immunoreactive to HNK-1 (data not shown).

\section{Discussion}

In addition to folding viral proteins involved in oncogenic transformation (Xu and Lindquist, 1993), HSP90 is upregulated several fold among a wide variety of mammalian tumors (Tsutsumi and Neckers 2007 for review). Taken together with a recently identified mitochondrial specific chaperoning complex in tumor cells (Kang et al., 2007) a significant role for extracellular HSP90 in cancer cell biology is evident. As a result of this intimate relationship between HSP90 function and neoplastic transformation and cell migration, some HSP90 inhibitors represent-
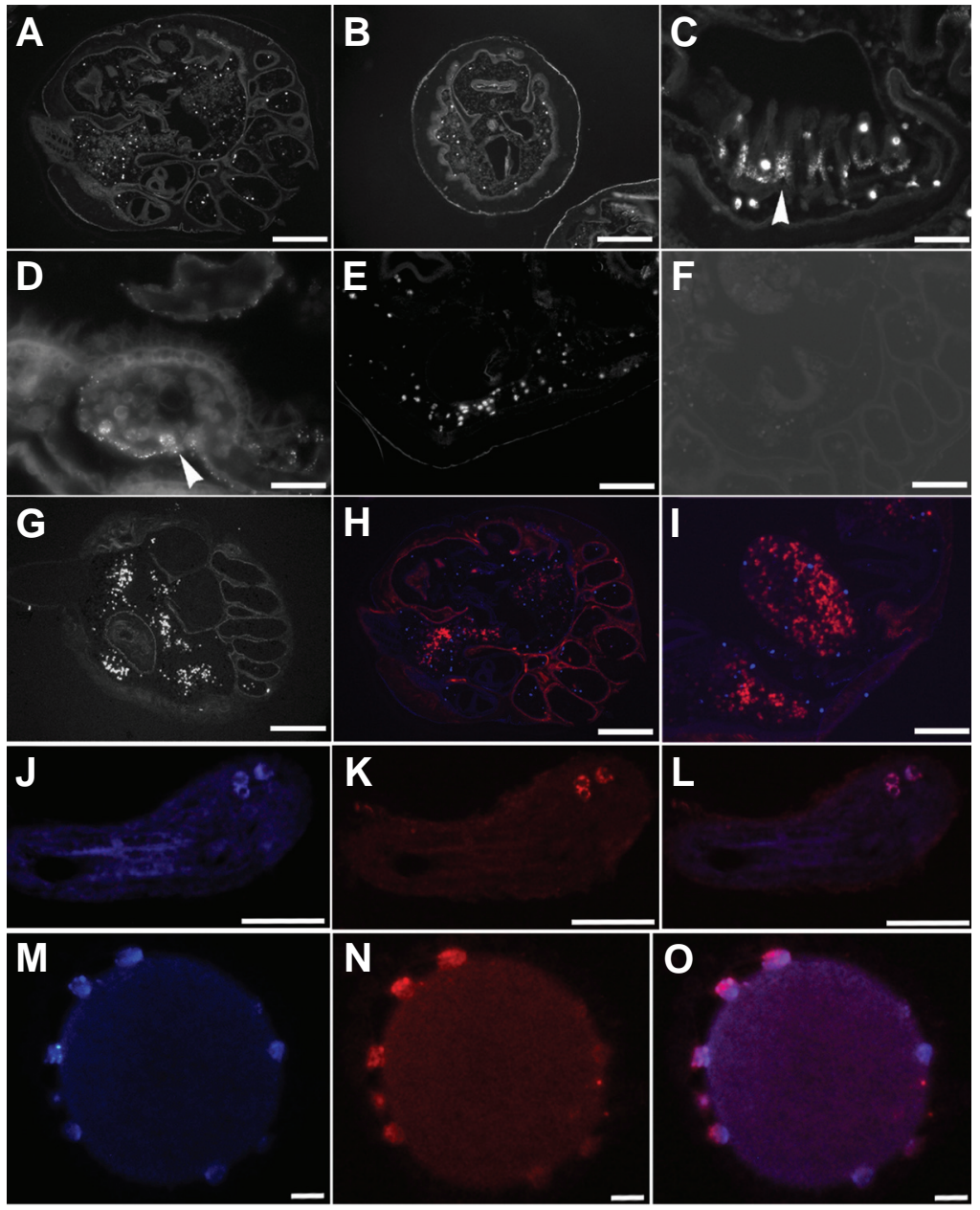

Fig. 5. Sections of $B$. violaceus (A-I) and B. villosa (J-L) larvae and B. villosa eggs (M-O) immunolabeled with AC88 and anti-HNK-1 antibodies. (A) Longitudinal section of the trunk of a larva. Immunoreactive cells are distributed throughout the trunk. (B) Transverse section of the trunk. (C) Protostigmata in which immunoreactivity is heterogeneously distributed (arrowhead). (D) Higher magnification view, showing the punctate staining present in both epithelium of the protostigmata and mesenchyme (arrowhead). The absence of staining on the opposite surface of the protostigmata corresponds to the absence of immunoreactive mesenchyme. (E) Positive control section for (F) a section treated with AC88 antibody preadsorbed with human HSP90. Both these images were collected using identical settings, but the brightness in F was increased to demonstrate the abolition of staining. (G) Longitudinal section immunostained with antiHNK-1. (H,I) Sagittal sections double stained with HNK-1 (red) and AC88 (blue). No overlap in immunoreactivity was observed between these two populations of mesenchyme. (J-K) Sagittal sections of B. villosa hatched larvae stained with AC88 and HNK-1 antibodies. (L) Merged images of $\mathrm{J}$ and $\mathrm{K}$ indicating that the immunoreaction corresponds to the same cells. (M) B. villosa egg stained with AC88. (N) Same section as in (A) stained with HNK-1. (0) Merged image from $(M, N)$. Scale bars are $100 \mu \mathrm{m}$ in $(A, B, G, H) ; 20 \mu \mathrm{m}$ in (D, M-O); $50 \mu \mathrm{m}$ in $(C, E, F, I-L)$.

ing distinct chemical classes of molecules are in various stages of clinical trials as human anti-cancer drugs (Tsutumi and Neckers, 2007).

Recent years have seen interest in molecular chaperones in general and HSP90 in particular extend from cell biology, biochemistry and biomedical sciences into development, evolution and ecology (e.g. Sass et al., 1996; D'Sousa and Brown, 1998;
Rutherford and Lindquist 1998; Roberts and Feder, 1999; Bishop et al., 2001; Bishop et al., 2002; Gunter and Degnan, 2007). Incisive inquiry into HSP90 function in animal development has historically been incidental (e.g. Ding et al., 1993; Cutforth and Rubin 1994) due in part to a lack of interest in what are percieved to be merely housekeeping genes (and therefore outside of the interest of most developmental biologists) but also to the difficulty 
in studying HSP90 function using forward genetics in animal models; mutant alleles of $h s p 83$ were rarely viable in fruit flies. The construction of strains of $D$. melanogaster with different heteroallelic combinations of hsp83 mutants allowed a nuanced and thorough investigation of HSP90 function in relation to morphogenesis (Rutherford and Lindquist, 1998). In this landmark paper Rutherford and Lindquist (1998) showed that, through its chaperoning function, HSP90 masked the phenotypic effects of mutations in protein coding genes. This masking effect was revealed by genetically or pharmacologically lowering HSP90 levels or from environmental stress. This and subsequent findings (Queisch et al., 2002; Milton et al., 2003; Milton et al., 2006; Suzuki and Nijhout, 2006; Yeyati et al., 2007; Connoly and Hall, 2008) have placed HSP90 at a focal point in the relationship between environmental stress and genotypic versus phenotypic change and has provided a (still somewhat vague) mechanistic basis for genetic assimilation and cannalization (Waddington, 1953a,b). Despite these advances, detailed reports of developmental function for HSP90 are rare but when elucidated they are fascinating (Ding et al., 1993; Cutforth and Rubin; Song et al., 2007) and serve to remind us about the false dichotomy between housekeeping and regulatory protein function during development. Taken together with recent work describing differential spatial and temporal expression of HSP70, HSP90 and HSF during development of a lophotrochozoan (Gunter and Degnan, 2007 ) it is clear that ongoing investigations into cell type specific function of molecular chaperones during development will be fruitful if not methodologically challenging.

Although considered to be exclusively a cellular protein, a growing literature is describing an extracellular distribution (and in some cases, a function) for HSP90. Originally identified as a tumour specific antigen in mice (Ullrich et al., 1986), HSP90 was identified as a secreted component of metastatic mammalian cells where it performs chaperoning roles for matrix metalloproteinase 2 (Eustace et al., 2004). A novel interaction between extracellular HSP90 and HER-2, a member of the ErbB family of receptor tyrosine kinases involved in cellular differentiation, migration, and cancer progression has recently been described (Sidera et al., 2008). Extracellular distributions of other components of the canonical HSP90 based chaperoning complex, including HSP70, p23 and Hop, have also been documented (Eustace and Jay 2004; Lee et al., 2006). Mammalian dermal fibroblast and neural cells deposit HSP90 into the extracellular matrix where it is required for migration and cytoskeletal modifications (Sidera et al., 2004; Li et al., 2007). Evidently, extracellular HSP90 is not a condition unique to cancer cells and may therefore have more general function during morphogenesis than currently appreciated.

Using urochordates, we demonstrate a second example of an association between elevated HSP90 expression and extracellular HSP90 in the context of cellular migration. This indicates that the condition of extracellular HSP9O is not restricted to neoplastic cells, nervous systems, or mammals, but is an emerging shared property of some migrating cells may therefore have more general function during morphogenesis.

\section{Test cells and the larval tunic}

Test cells express elevated levels of HSP90 from late stage oogenesis until the mid-tail stage. Immunoblot analyses verified the specificity of the antibody and indicated a single protein or two closely migrating proteins of $\sim 80 \mathrm{kD}$ that cross-react with AC88. A comprehensive bioinformatic analysis of genes encoding HSP90 indicates that the Ciona intestinalis nuclear genome contains two, one of which is predicted to encode a protein of $83.3 \mathrm{kD}$ (Chen et al., 2006). By manual dechorionation we removed test cells from the surface of zygotes and showed that such embryos contain less HSP90 than control embryos. The HSP90 was restricted to test cells until the mid tail stage at which point it simultaneously became undetectable in test cells and appeared on the larval tunic indicating that $B$. villosatest cells contain and deposit HSP90 on the larval tunic. The removal of test cells from tail bud embryos resulted in the abrogation of immunoreactivity on larval tunics, verifying the observation that test cells deposit HSP90 on the larval tunic. Given that some test cells in $C$. intestinalis undergo apoptosis (Maury et al., 2006), it remains possible that the observed deposition on to the tunic of HSP90 by $B$. villosa test cells is the result of apoptosis and is therefore not an active mechanism by which test cells to modify the larval tunic. In contrast to the findings of Maury et al. (2006) widespread apoptosis of test cells in $B$. villosa has not been observed to occur (Bates, 2004). Moreover, the cytoplasm of apoptotic cells is always surrounded by membrane, precluding the release of cellular contents into the immediate cellular, or in this case acellular, milieu.

The present results extend those of Takamura etal. (1996) and Okada et al. (1996) in which the larval tunic includes a proteinaceous component generated, in part or in whole, by the test cells. The antigens reported in Takamura et al. (1996) and Okada et al. (1996) have not been characterized and thus, HSP90 is the first identified protein that is deposited from the test cells on to the larval tunic. The mechanism by which test cells release their contents is not known, but test cells of Styela plicata can be induced to release heparin and histamine by the mammalian mast cell secretagogue compound 48/80 (Cavalcante et al., 2002), invoking GTPase and phospholipase C- and D- activity (Chahdi et al., 1998a,b, 2000; Mousli et al., 1990; Senyshyn et al., 1998).

Two observations indicate an evolutionary association of test cells and larval tunics: (i) Embryos of larvaceans, the sister taxon to Ascidians + Thalaceans (Wada, 1992), do not contain test cells (Cloney, 1990) and do not have a larval stage, (ii) Embryos of the direct developing ascidian Molgula pacifica do not contain test cells (Young et al., 1988; Bates and Mallet, 1991; Cloney, 1994). For reasons that are still not clear, but are almost certainly related to the deposition of materials by test cells discussed above, this association may be required to render the tunic an adaptive structure.

Cloney's hypothesis that test cells render the tunic hydrophilic or 'wettable' is attractive; the external covering of any small marine organism must be sufficiently hydrophilic to avoid getting stuck at the air water interface. The removal of test cells from neurulae generated larvae with poorly formed fins and such larvae stuck to each other and to glass surfaces (Cavey and Cloney, 1982). However, experimentally induced hydrophobicity by removal of test cells may be a secondary effect and not reflect the primary function of the material released from test cells. The ascidian tunic, although historically considered to be composed primarily of carbohydrates, was shown to be $50 \%$ protein (Smith and Dehnel, 1970). If this can be generalized across species and 
to the larval tunic, the role of a molecular chaperone in this external milieu becomes less peculiar in light of its emerging function as a chaperone that is capable of functioning extracellularly (Eustace et al., 2004). Cloney (1990) observed that test cells of some species adhere to larval tunics, whereas in others, test cells are lost at hatching. Given this variation among species it should be possible to further elucidate any relationship between the deposition of HSP90 and the subsequent migration of test cells.

\section{Trunk lateral cells}

As one of multiple distinct populations of larval mesenchyme, TLCs exist at hatching in the dorsolateral region of the trunk. Based on the similar position at hatching of HSP90-positive cells in $B$. villosato TLCs in $H$. roretzi, we hypothesized that the former were TLCs. This idea was tested and supported by removing the embryonic lineage that gives rise to the TLCs. We based this experiment on the assumption that TLC cell lineages between $B$. villosa and $H$. roretziare conserved. Because these two species are in the family Pyuridae and because the TLCs are derived from the A7.6 blastomeres in both $H$. roretzi (Pyuridae) (Nishida and Satoh, 1987) and C. savignyi(Styelidae) (Tokuoka et al., 2005), this assumption is reasonable. The A5.2 lineage was not fate restricted at the time of extirpation. Other fates besides TLCs include notochord, endoderm, tail muscle and nerve cord (Nishida and Satoh, 1987). Thus, it is possible that elevated HSP90 expression is localized to a non-TLC population of mesenchyme and that the abolition of immunoreactivity was due to the loss of conditional specification of non-TLC mesenchyme by cells of the A5.2 lineage. By virtue of their position in cleavage arrested embryos, HNK-1 labeled cells were identified as TLCs in Ciona intestinalis (Jeffery et al., 2008). Together with the blastomere ablation experiments here, their position at hatching and the observation in $B$. villosathat $\mathrm{HNK}-1$ and $\mathrm{HSP} 90$ are present in the same cell strongly supports the conclusion that the cells expressing elevated levels of HSP90 are TLCs.

In contrast to the test cells, TLCs are immunoreactive between hatching and metamorphosis. Loss of HSP90 expression in TLCs occurs 24 hours after tail resorption is initiated and appears to be responsive to the induction of metamorphosis. The punctate pattern of intracellular localization of HSP90 in test cells and TLCs is consistent with it being membrane bound in cisternae of the ER or perhaps in secretory vesicles such as exosomes.

It is notable that both cell types that express elevated levels of HSP90 are migratory, but not all migratory cells in larvae express elevated levels of HSP90. For example, there are four distinct lineages of mesenchymal cells in the ascidian tadpole, defined by embryonic origins, fates and gene expression patterns (Nishida and Satoh, 1987; Sotgia et al., 1993; Hirano and Nishida, 1997; Tokuoka et al., 2004). Only one of these appears to require elevated HSP90 for its function. Moreover, in $B$. violaceus we observed that HNK-1 positive mesenchyme, at least some of which are migratory presumptive pigment cells (Jeffery, 2006), did not express elevated HSP90, suggesting no particular requirement for HSP90 compared to their HSP90 positive mesenchymal counterparts. In B. violaceuswe observed HSP90 expression in the protostigmata, perhaps the result of a contribution from HSP90 positive mesenchyme. Because TLCs contribute to the pharynx in $C$. intestinalis and $C$. savigny (Hirano and Nishida,
1997; Tokuoka, 2005) and because HSP90 is expressed in TLCs in several taxa, it is likely that the HSP90 positive mesenchyme in $B$. violaceous is homologous to TLCs.

We documented the expression of HSP90 in larval mesenchyme from four species representing two of the three orders of ascidians, indicating that this may be a character shared by the entire class. In $B$. violaceus, we tested the possibility that the mesenchyme immunoreactive for AC88 were the same cells observed by Jeffery (2006) to express HNK-1 a marker of presumptive pigment cells. We observed no overlap in staining between these cells, suggesting no developmental relationship in this species at this stage. We consider it interesting that HNK-1 and HSP90 expression overlap in the relatively simple larva of a solitary ascidian but not in the highly adultated larvae of a compound ascidian. One possibility is that HSP9O and HNK-1 expressing cells in $B$. violaceous share embryonic origin but differentiate into two populations prior to hatching.

\section{A relationship between test cells and some TLC descen- dants?}

Because one of two competing hypotheses about the origin of test cells posits that they are trans-differentiated ameboid or lymphocytic blood cells, and because hemocytes ('blood' cells) are one of the fates of TLCs, emerging similarities between test cells and some of the TLCs descendants warrant further consideration.

In this paper we show that the two cell types that express elevated HSP90 are migratory and associate with the tunic, suggesting functional similarities. This similarity was further demonstrated by immunolabeling experiments with anti-HNK-1, in which both test cells and trunk lateral cells were stained. A third connection between test cells and trunk lateral cells has been revealed by investigations into the presence of heparin and histamine in ascidians (Cavalcante et al., 2000, 2002). In vertebrates, these molecules are associated with immunologic function and are secreted exclusively by a subtype of mast cell. There are three cell types in the ascidian Styela plicata that are known to contain both heparin and histamine: test cells, granulocytes (a type of hemocyte) and cells lining the pharynx (Cavalcante et al., 2000; Cavalcante et al., 2002; de Barros et al., 2007). Again, given the 'blood' cell fate of some TLC descendants (although their specific fate with respect to function is not known) and the contribution of TLC descendants to the epithelium lining the stigmata (Hirano and Nishida, 1997; Tokuoka, 2005) the shared presence of heparin and histamine between these three cell types is intriguing. Fourth, as a peripheral observation, Takamura et al. (1996) noted that unidentified larval mesenchyme appeared to contain antigens that bound one of their 'test cell-specific' antibodies. They also noticed this immunoreaction in adult 'blood' cells. It is possible that the mesenchyme Takamura et al. (1996) observed to express the antigen recognized in the test cells were descendents of TLCs. A fifth, albeit weaker, similarity between test cells and trunk lateral cells is informed by the work of Sato and Morisawa (1999) in which it was shown that new cells emigrate from developing $C$. intestinalis embryos if the test cells are removed by dechorionation. We and others have observed that TLCs cross the anterior trunk epithelium shortly after hatching. Thus, TLCs constitute a cell population that can cross the larval epithelium and populate the exterior of the animal. Although, for 
reasons of timing, Sato and Morisawa argued against the possibility that the replacement cells they observed were TLCs, this possibility has not been experimentally falsified.

We suggest that test cells and the fraction of trunk lateral cell descendants that become 'blood' cells are functionally and ontogenetically related. That is, we hypothesize that test cells are descendants of the TLCs. The ability to generate long term (genetic) labeling of trunk lateral cells will be required to falsify this hypothesis.

\section{TLCs and the origin of the neural crest}

On the basis of gene expression studies it has recently been reported that trunk lateral cells are neural crest-like (Jeffery et al., 2008). Although we agree with this general assertion (i) earlier reports indicate that TLCs are part of a population of mesenchymal precursors of adult mesoderm. (Hirano and Nishida, 1997; Tokuoka et al., 2004; Tokuoka, 2005) and (ii) no TLC descendents are known to differentiate as neurons. Based on the presence of heparin and histamine (Cavalcante et al., 2000; Cavalcante et al., 2002), test cells are proposed to be homologous with (mesodermally derived) mammalian mast cells. If test cells are in fact descendants of TLCs, and if ascidian test cells and mammalian mast cells are homologous, then TLCs appear to have properties and fates attributable to both vertebrate mesoderm and neural crest. Although anti-HNK-1 is a neural crest marker (Tucker etal., 1984), the antigen from which it was derived was extracted from human large granular lymphocytes (Abo and Balch, 1981). Later this antigen was found to be identical to that which generated the antibody NC1 from extracts of quail ciliary ganglion (Vincent and Thiery, 1984). Here in a urochordate we observe that the HNK-1 antigen appears to be present in test cells and trunk lateral cells, two cell types that, respectively, have been homologized with vertebrate mesodermal and neural crest cells (Cavalcante 2002, Jeffery et al., 2008). The implications for current models of neural crest origin and evolution are fascinating indeed.

\section{Materials and Methods}

\section{Immunohistochemistry and immunoblotting}

Specimens were fixed in methanol and ethanol $\left(-20^{\circ} \mathrm{C}\right)$ for twenty minutes each and then embedded and sectioned as previously described (Bates, 1988) or stained processed as whole mounts. The anti-HSP90 antibody was monoclonal (clone AC88; Stressgen Biotechnologies, Victoria B.C.) and the antigen used for immunization was purified from bovine brain. This antibody recognizes HSP90 from species as diverse as water molds and vertebrates and was thus judged to be suitable as a heterologous antibody. Sections were incubated for two hours at room temperature in a dilution of $1: 100-1000$ AC88 from a $1 \mu \mathrm{g} / \mathrm{mL}$ stock whereas whole mounts were incubated in a 1:100 dilution overnight at $4 \mathrm{C}$. Antibody was diluted in blocking buffer (2.5-5\% bovine serum albumin with $0.05-0.1 \%$ Triton-X-100 in PBS pH 7.4). After washing the primary antibody in blocking buffer, sections were incubated with goat anti-mouse IgG conjugated to FITC or Alexa 488 for $1 \mathrm{~h}$ at room temperature (Sigma or Molecular Probes). After final rinses in PBS, specimens were mounted in $70 \%$ glycerol in PBS and viewed using an Olympus fluorescence microscope, a Zeiss LSM410 confocal microscope or a Zeiss AxioPlan epifluorescence microscope. Variously, omission of the primary antibody, the use of a non-relevant antibody or pre-adsorption of the primary antibody with a $5 \mathrm{X}$ molar excess of purified bovine HSP90 (Stressgen Biotechnologies Inc.) served as controls.
Immunoblotting was performed essentially as described in Bates and Bishop (1996). Samples were centrifuged briefly, seawater was aspirated with a fine pipette and samples were lysed directly in 1X Laemmli sample buffer. Lysates were centrifuged at 10,000 rpm for 5 min before placing the supernatant in a boiling water bath for $4 \mathrm{~min}$ prior to use or storage at $-70 \mathrm{C}$. Purified bovine HSP90 was prepared for electrophoresis in the same manner and used as a positive control. Proteins were separated by electrophoresis on 8 or $10 \%$ discontinuous polyacrylamide gels in SDS and blotted onto PVDF membrane (Bio-Rad). AC88 was applied at $1: 1000$ at $4 \mathrm{C}$ overnight, while goat anti-mouse IgG conjugated to HRP was applied at 1:1000 or 1:2000 at room temperature for $2 \mathrm{~h}$. ECL (Amersham Pharmacia) detection was carried out according to the manufacturer's instructions.

\section{Microsurgical manipulations}

To prepare material for immunoblotting, 20 zygotes were manually dechorionated using steel insect pins (Elephant brand \#2 or \#3) mounted on Pasteur pipettes, as described by Bates and Jeffery (1987) and then transferred to a separate Syracuse dish. After verifying that no test cells were transferred, the dechorionated zygotes were placed in microfuge tubes and processed as above. For blastomere ablation experiments zygotes were dechorionated after the first stage of ooplasmic segregation (20 minutes after insemination), and then cultured in Syracuse dishes coated with $0.9 \%$ agar. At the 16 -cell stage A5.2 blastomeres were manually cytolysed by disrupting the plasma membranes with a sharpened steel needle. Shortly after cytolysis blastomeres turned white and became loosely associated with the embryo. These were removed by gently pipetting the embryo. Embryos lacking the A5.2 blastomeres were then cultured until the controls hatched, and then fixed and embedded as described by Bates (1988). For experiments that verified the deposition of HSP90 from test cells, tailbud stage embryos (18-20 hours post insemination at 13C) were dechorionated and then cultured until the controls hatched. These and controls were fixed for whole mount immunocytochemistry as above except that larvae were incubated in primary antibody at 1:100 at $4 \mathrm{C}$ overnight and secondary antibody at 1:200 overnight at $4 \mathrm{C}$.

\section{Acknowledgements}

This paper is dedicated to the memory of Dr. JR Whittaker, one of the grand masters of ascidian experimental embryology. The authors acknowledge the support of NSERC through Discovery grants (17296-02) to WRB and (A5056) to BKH.

\section{References}

ABO T. and BALCH C.M. (1981). A differentiation antigen of NK and $\mathrm{K}$ cells identified by a monoclonal antibody (HNK-1). J Immuno/127: 1024-1029.

DE BARROS C.M., ANDRADE L.R., ALLODI S., VISKOV C., MOURIER P.A., CAVALCANTE M.C.M., STRAUS A.H., TAKAHASHI H.K., POMIN V.H., CARVALHO V.F., MARTINS M.A., and PAVÃO M.S.G. (2007). The hemolymph of the ascidian Styela plicata (Chordata-Tunicata) contains heparin inside basophil-like cells and a unique sulfated galactoglucan in the plasma. $J$ Biol Chem 282: 1615-1626.

BATES W.R. (1988). Development of myoplasm enriched ascidian embryos. Dev Biol129: 241-252

BATES W.R. (2004). Cellular features of an apoptotic form of programmed cell death during development of the ascidian, Boltenia villosa. Zool Sci 21: 553 563.

BATES W.R. and BISHOP C. (1996). Localization of constitutive heat shock proteins in developing ascidians. Deve/ Growth and Differ 38: 307-314.

BATES W.R. and JEFFERY W.R. (1987). Alkaline phosphatase expression in ascidian egg fragments and andromerogons. Dev Bio/119: 382-389.

BATES W.R. and MALLET J.E. (1991). Ultrastructural and histochemical study o anural development in the ascidian Molgula pacifica (Huntsman). Roux's Arch Dev Bio/200: 193-201. 
BISHOP C.D., BATES W.R. and BRANDHORST, B.P. (2001). Regulation of metamorphosis in ascidians involves NO/cGMP signaling and HSP90. J EXp Zoo/289: 374-384.

BISHOP C.D., BATES W.R. and BRANDHORST, B.P. (2002). HSP90 function is required for morphogenesis in ascidian and sea urchin embryos. Dev Genes Evol212: 70-80.

CAVALCANTE M.C., ALLODI S., VALENTE A.P., STRAUS A.H., TAKAHASHI H.K., MOURÃO P.A., PAVÃO M.S. (2000). Occurrence of heparin in the invertebrate Styela plicata (Tunicata) is restricted to cell layers facing the outside environment. An ancient role in defense? J Biol Chem 275: 3618936196.

CAVALCANTE M.C., DE ANDRADE L.R., DU BOCAGE SANTOS-PINTO C., STRAUS A.H., TAKAHASHIH.K., ALLODIS., PAVAOM.S. (2002). Colocalization of heparin and histamine in the intracellular granules of test cells from the invertebrate Styela plicata (Chordata-Tunicata). J Struct Bio/137: 313-321.

CAVEY M.J. (1976). Ornamentation of the larval tunic by test cells. JUItrastructural Res 55: 297-298.

CHAHDI A., DAEFFLER L., GIES J.P. and LANDRY Y. (1998). Drugs interacting with $\mathrm{G}$ protein a subunits: selectivity and pespectives. Fundam Clin Pharmacol 12: 121-132.

CHAHDI A., MOUSLI M. and LANDRY Y. (1998). Substance P-related inhibitors of mast cell exocytosis act on $\mathrm{G}$ proteins or on the cell surface. Eur J Pharmacol 341: 329-335.

CHAHDI, A., FRAUNDORFER P.F. and BEAVEN M.A. (2000). Compound 48/80 activates mast cell phospholipase D via heterotrimeric GTP-binding proteins. $J$ Pharmacol Exp Ther 292: 122-130.

CHEN B., ZHONG, D. and MONTEIRO A. (2006). Comparative genomics and evolution of the HSP90 family of genes across all kingdoms of organisms. BMC Genomics 7: 156-175.

CLONEY R.A. (1990). Larval tunic and the function of the test cells in ascidians. Acta Zoologica 71: 151-159.

CLONEY R.A. (1994). Test cell secretions and their functions in ascidian development. In: Reproduction and Development of Marine Invertebrates. (Eds. Wilson WH, Stricker SA and Shinn GL). Johns Hopkins University Press, Baltimore, USA.

CLONEY R.A. and CAVEY M.J. (1982). Ascidian larval tunic: Extraembryonic structures influence morphogenesis. Cell Tissue Res 222: 547-562.

CONNOLY M.H. and HALL B.K. (2008). Embryonic heat shock reveals latent hsp90 translation in zebrafish (Danio rerio). Int J Dev Bio/52: 71-79.

CUTFORTH T. and RUBIN G.M. (1994). Mutations in Hsp83 and cdc37 impair signaling by the sevenless receptor tyrosine kinase in Drosophila. Cel/77: 10271036.

DING D., PARKHURST S.M., HALSELL S.R., and LIPSHITZIH.D. (1993). Dynamic Hsp83 RNA localization during Drosophila oogenesis and embryogenesis. Mol Cel Biol13: 3773-3781.

D'SOUSA S.M. and BROWN I.R. (1998). Constitutive expression of heat shock proteins Hsp90, Hsc70, Hsp70 and Hsp60 in neural and non- neuronal tissues of the rat during postnatal development. Cell Stress Chaperones 3:188-199.

EUSTACE B.K., SAKURAI T., STEWART J.K., YIMLAMAI D., UNGER C., ZEHETMEIER C., LAIN B., TORELLA C., HENNING S.W., BESTE G., SCROGGINS B.T., NECKERS L., ILAG L.L. and JAY D.G. (2004). Functional proteomic screens reveal an essential role for extracellular HSP90 alpha in cancer cell invasiveness. Nat Cel/ Bio/6: 507-514.

EUSTACE B.K. and JAY D.G. (2004). Extracellular roles for the molecular chaperone HSP90 Cell Cycle 3: 1098 -1100.

GUNTER H.M. and DEGNAN M.B. (2007). Developmental expression of Hsp90, Hsp70 and HSF during morphogenesis in the vetigastropod Haliotis asinina Dev Genes Evol217: 603-612.

HIRANO T. and NISHIDA H. (1997). Developmental fates of larval tissues after metamorphosis in ascidian Halocynthia roretzi. I. Origin of mesodermal tissues of the juvenile. Dev Bio/192: 199-210.

JEFFERY W.R. (2006). Ascidian Neural Crest-Like Cells: Phylogenetic Distribution, Relationship to Larval Complexity, and Pigment Cell Fate. J Exp Zool (Mol Dev Evol) 306B: 470-480.

JEFFERY W.R., CHIBA T., KRAJKA F.R., DEYTS C., SATOH, N. and JOLY J.-S.
(2008). Trunk lateral cells are neural crest-like cells in the ascidian Ciona intestinalis: Insights into the ancestry and evolution of the neural crest. Dev Biol 324:152-160.

KANG B.H., PLESCIA J., DOHI T., ROSA J., DOXSEY S.J. and ALTIERI D.C .(2007). Regulation of Tumor Cell Mitochondrial Homeostasis by an OrganelleSpecific Hsp90 Chaperone Network. Ce//131: 257-270.

LEE K.J., KIM Y.M., KIM D.Y., JEOUNG D., HAN K., LEE S.T., LEE Y.S. and PARK K.H. (2006). Release of heat shock protein 70 (Hsp70) and the effects of extracellular Hsp70 on matrix metalloproteinase-9 expression in human monocytic U937 cells. Exp Mol Med38: $364-374$.

LI W., LI Y., GUAN S., FAN J., CHENG C.-F., BRIGHT A.M., CHINN C., CHEN M and WOODLEY D.T. (2007). Extracellular heat shock protein-90alpha: linking hypoxia to skin cell motility and wound healing. Embo J26: 1221-33.

MAURY B., MARTINAND-MARI C., CHAMBON J.P., SOUL J., DEGOLS G., SAHUQUET A., WEILL M., BERTHOMIEU A., FORT P., MANGEAT P., BAGHDIGUIANS. (2006). Fertilization regulates apoptosis of Ciona intestinalis extra-embryonic cells through thyroxine (T4)-dependent NF-kappaB pathway activation during early embryonic development. Dev Bio/289: 152-165.

MILTON C.C., HUYNH B., BATTERHAM P., RUTHERFORD S.L., HOFFMANN A.A. (2003). Quantitative trait symmetry independent of Hsp90 buffering: distinct modes of genetic canalization and developmental stability. Proc Nat/ Acad Sci USA 100: 13396-13401.

MILTON C.C., ULANE C.M. and RUTHERFORD S. (2006). Control of Canalization and Evolvability by Hsp90. PLOS One. 1: 1-12.

MONNIOT F., MARTOJA R., TRUCHET M. and FROHLICH F. (1992). Opal in ascidians: A curious bioaccumulation in the ovary. Mar Biol112: 283-292.

MOUSLI M., BUEB J.-L., BRONNER C., BAND R. and LANDRY Y. (1990). Gprotein activation: a receptor-independent mode of action for cationic amphiphilic neuropeptides and venom peptides. Trends Pharmacol Sci11, 358-362.

NISHIDA H. and SATOH N. (1987). Cell lineage analysis in ascidian embryos by intracellular injection of a tracer enzyme. III. Up to the tissue restricted stage. Dev Biol121: 526-541.

NISHIDE K., NISHIKATA T. and SATOH N. (1989). A monoclonal antibody specific to embryonic trunk lateral cells of the ascidian Halocynthia roretzi stains coelomic cells of juvenile and adult basophilic blood cells. Develop Growth Differ 13: 595-600.

OKADA T., TAKAMURA K., YAMAGUCHI Y. and YAMAMOTO M. (1996). Secretory function of the test cell in larval tunic formation in the ascidian Ciona intestinalis: An immunoelectron study. Zoological Science 13: 253-261.

QUEITSCH C., SANGSTER T.A. and LINDQUIST S. (2002). Hsp90 as a capacitor of phenotypic variation. Nature 417: 618-624.

ROBERTS S.P. and FEDER M.E. (1999). Natural hyperthermia and expression of the heat shock protein Hsp70 affect developmental abnormalities in Drosophila melanogaster. Oecologia 121: 323-329.

ROBINSON W.E., KUSTINK. and CLONEY R.A. (1986). The influence of tunichrome and other reducing compounds on tunic and fin formation in embryonic Ascidia callosa Stimpson. J Exp Zoo/237: 63-72.

RUTHERFORD S. and LINDQUIST S. (1998). Hsp90 as a capacitor for morphological evolution. Nature 396: 336-342.

SASS J.B., WEINBERG E.S. and KRONE P.H. (1996). Specific localization of zebrafish hsp90a mRNA to myoD-expressing cells suggests a role for hsp90a during normal muscle development. Mech Dev 54:195-204.

SATO Y., TERAKADO K. and MORISAWA M. (1997). Test cell migration and tunic formation during post-hatching development of the larva of the ascidian Ciona intestinalis. Develop Growth Differ 39: 117-126.

SATOY. and MORISAWA M. (1999). Loss of test cells leads to the formation of new tunic surface cells and abnormal metamorphosis in larvae of Ciona intestinalis (Chordata, Ascidiacae). Dev Genes Evo/209: 592-600.

SENYSHYN J., BAUMGARTNER R.A. and BEAVEN M.A. (1998). Quercetin sensitizes RBL-2H3 cells to polybasic mast-cell secretagogues through increased expression of Gi GTP-binding proteins linked to a phospholipase C signaling pathway. J Immuno/160, 5136- 5144.

SIDERA K., SAMIOTAKI M., YFANTI E., PANAYOTOU G., and PATSAVOUDI E. (2004). Involvement of cell surface HSP90 in cell migration reveals a novel role in the developing nervous system J Biol Chem 279: 45379-45388. 
SIDERA K., GAITANOU M., STELLAS D., MATSAS R. and PATSAVOUDI E. (2008). A critical role for HSP90 in cancer cell invasion involves interaction with the extracellular domain of HER-2. J Biol Chem 283: 2031-2041.

SMITH M.J. (1970). The blood cells and tunic of the ascidian Halocynthia aurantium (Pallas). I. Hematology, tunic morphology, and partition of cells between blood and tunic. Biol Bull138: 354-388.

SMITH M.J. and DEHNEL P.A. (1970). The chemical and enzymatic analyses of the tunic of the ascidians Halocynthia aurantium (Pallas) Comp Biochem Physiol 35: $17-30$.

SONG Y., FEE L., LEE T.H. and WHARTON R.P. (2007). The molecular chaperone Hsp90 is required for mRNA localization in Drosophila melanogasterembryos. Genetics 176: 2213-22.

SOTGIA C., FASCIO, U., ORTOLANI G. and DE BERNARDI F. (1993). Behavior of endodermal «button cells» during metamorphosis of ascidian larvae. Int $J$ Dev Bio/37: 547-55.

SUZUKI Y. and NIJHOUT H.F. (2006). Evolution of a polyphenism by genetic accommodation. Science 311:650-652.

TAKAMURA K., UEDA Y., IRIE U. and YAMAGUCHI Y. (1996). Immunohistology with antibodies specific to test cells in the ascidian Ciona intestinalis suggests their role in larval tunic formation. Zoological Science 13: 241-251.

TOKUOKA M., IMAI K.S., SATOU Y. and SATOH N. (2004). Three distinct lineages of mesenchymal cells in Ciona intestinalis embryos demonstrated by specific gene expression. Dev Bio/274: 211-224

TOKUOKA M., SATOH N., SATOU Y. (2005). A bHLH transcription factor gene, Twist-like1, is essential for the formation of mesodermal tissues of Ciona juveniles. Dev Bio/288: 387 - 396.

TUCKER G.C., AOYAMA H., LIPINKSI M., TURSZ T., THIERY J.P. (1984). Identical reactivity of monoclonal antibodies HNK-1 and NC-1: conservation in vertebrates on cells derived from the neural primordium and on some leukocytes. Cel/ Differ 14: 223-230.

TSUTSUMI S., NECKERS L. (2007). Extracellular heat shock protein 90: A role for a molecular chaperone in cell motility and cancer metastasis. Cancer Sci98. 1536-39.

ULLRICH S.J., ROBINSON E.A., LAW L.W., WILLINGHAM M., APPELLA E. (1986). A mouse tumor-specific transplantation antigen is a heat shock-related protein. Proc Natl Acad Sci USA 83: 3121-5.

VINCENT M., THIERY J.P. (1984). A cell surface marker for neural crest and placodal cells: further evolution in peripheral and central nervous system. Dev Biol 103: 468-481.

WADA H. (1992). Evolutionary history of free-swimming and sessile lifestyles in urochordates as deduced from 18S rDNA molecular phylogeny. Mol Biol Evol 15: 1189-1194.

WADDINGTON C.H. (1953a). Genetic assimilation of an acquired character Evolution 7: 118-126.

WADDINGTON C.H. (1953b). The «Baldwin effect,» «genetic assimilation» and «homeostasis». Evolution 7: 386-387.

WARDROP A.B. (1970). The structure and formation of the test of Pyura stolonifera (Tunicata). Protoplasma 70: 73-86.

XU Y., LINDQUIST S. (1993). HSP90 governs the activity of pp60v-src kinase. Proc Natl Acad Sci USA. 90: 7074-7078.

YEYATI P.L., BANCEWICZ R.M., MAULE J., VAN HEYNINGEN V. (2007). Hsp90 Selectively Modulates Phenotype in Vertebrate Development. PLOS Genetics 3: 431-447.

YOUNG C.M., GOWAN R.F., DALBY J., PENNACHETTI C.A., GAGLIARDI D. (1988). Distributional consequences of adhesive eggs and anural development in the ascidian Molgula pacifica (Huntsman, 1912). Biol Bull174: 39-46.
Further Related Reading, published previously in the Int. J. Dev. Biol.

See Special Issue Pattern Formation edited by Michael K. Richardson and Cheng-Ming Chuong at:

http://www.ijdb.ehu.es/web/contents.php?vol=53\&issue=5-6

Embryonic heat shock reveals latent hsp90 translation in zebrafish (Danio rerio) Michelle H. Connolly and Brian K. Hall

Int. J. Dev. Biol. (2008) 52: 71-79

Blind cavefish and heat shock protein chaperones: a novel role for hsp90alpha in lens apoptosis

Thomas A. Hooven, Yoshiyuki Yamamoto and William R. Jeffery

Int. J. Dev. Biol. (2004) 48: 731-738

Behavior of endodermal «button cells» during metamorphosis of ascidian larvae C Sotgia, U Fascio, G Ortolani and F De Bernardi

Int. J. Dev. Biol. (1993) 37: 547-553
5 yr ISI Impact Factor $(2009)=3.253$

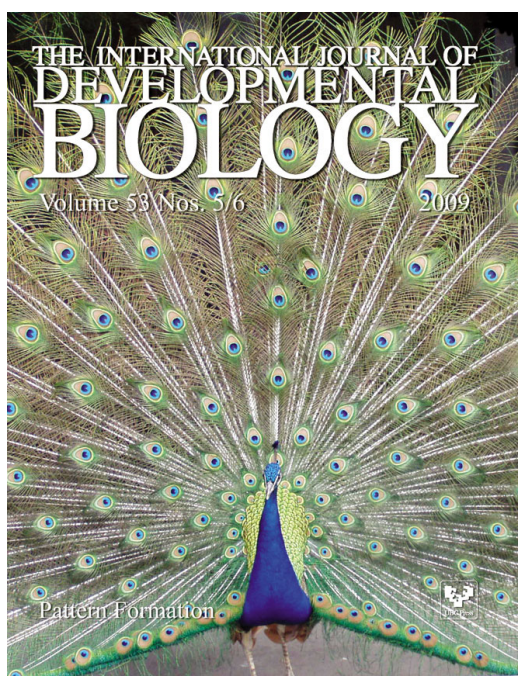

